\title{
МАТРИЧНАЯ ПОЛИМЕРИЗАЦИЯ ИОННЫХ МОНОМЕРОВ НА САМООРГАНИЗУЮЩИХСЯ СТРУКТУРАХ КАК ТЕХНОЛОГИЧНЫЙ СПОСОБ ПОЛУЧЕНИЯ (МУЛЬТИ) ЛИПОСОМАЛЬНЫХ СТРУКТУР ДЛЯ АДРЕСНОЙ ДОСТАВКИ ЛЕКАРСТВЕННЫХ СРЕДСТВ
}

\author{
Ю.В. Шулевич, Л.Р. Лишнева, А.В. Навроцкий, И.А. Новаков
}

Волгоградский государственный технический университет, 400005, Россия, Волгоград, проспект им. В.И. Ленина, 28.

DOI: 10.19163/MedChemRussia2021-2021-225

E-mail: yanalieva.laura@yandex.ru

Развитие современной медицины и фармакологии неразрывно связано с понятием направленного транспорта лекарственных веществ, который позволяет увеличить концентрацию лекарственных веществ в больном органе или тканях, в то время как накопление этого же вещества в здоровых органах и тканях оказывается незначительным или, вовсе блокированным. Одним из перспективных направлений в этой области исследования является инкапсулирование лекарственных средств в бислойные липидные везикулы (липосомы). К сожалению, ограниченный внутренний объем липосом не позволяет иммобилизировать в них достаточное количество лекарственных средств. Возможным вариантом решения этой проблемы является формирование, так называемой, (мульти)липосомальной структуры, представляющей собой комплекс полиэлектролит - липосома.

Для фундаментальных исследований способ получения (мульти)липосомальных контейнеров достаточно прост и заключается в смешении готовых разбавленных растворов полиэлектролитов и липосом. В лаборатории, и даже на пилотных установках это несложно реализовать. Однако, с целью промышленной реализации технологии создания таких контейнеров необходимо учесть множество факторов, чтобы в результате получить эффективную с точки зрения экономики и производительности промышленную технологию. Современная химия полимеров предлагает простое и технологичное решение этой задачи - матричный синтез.

7. В настоящей работе для синтеза модельных липосомальных структур использовали два поверхностно-активных вещества: натрия диоктилсульфосукцинат (АОТ) и кокамидопропилбетаин (КАПБ). Синтез липосомальных структур осуществляли, используя в качестве растворителя фосфатный буфер (тетраборат натрия/дигидрофосфат калия; $\mathrm{pH}=7.2$ ). Обсуждается влияние концентрации компонентов, мольного соотношения АОТ/КАПБ и условий синтеза на свойства полученных липосомальных структур, а также их взаимодействие с ионогенным катионным мономером. 